\title{
Stanisław Wieteska
}

Uniwersytet Jana Kochanowskiego w Kielcach

\section{Patrycja Kowalczyk-Rólczyńska}

Uniwersytet Ekonomiczny we Wrocławiu

e-mail: patrycja.kowalczyk@ue.wroc.pl

\section{Agnieszka Czajkowska}

Uniwersytet Łódzki

e-mail: agnieszka.czajkowska@uni.lodz.pl

\section{UBEZPIECZENIE ODPOWIEDZIALNOŚCI CYWILNEJ POŚREDNIKA KREDYTU HIPOTECZNEGO}

\section{THE MORTGAGE LOAN INTERMEDIARY}

LIABILITY INSURANCE

DOI: $10.15611 / \mathrm{pn} .2018 .541 .23$

JEL Classification: D18, D14, G21

Streszczenie: Kryzys finansowy z lat 2007-2009 doprowadził do tego, że za pomocą odpowiednich dyrektyw podjęto radykalne działania mające na celu ochronę konsumenta jako słabszej strony umowy kredytowej. Wśród wielu decyzji szczególną uwagę zwrócono na sposób zawierania przez pośredników umów kredytów hipotecznych. Na pośredników kredytu hipotecznego, oprócz wielu wymagań, nałożono obowiązek zawarcia umowy ubezpieczenia odpowiedzialności cywilnej. Artykuł naświetla problematykę kredytów hipotecznych w Polsce i obszernie ustosunkowuje się do treści zapisów zawartych w aktach prawnych. W szczególności zwrócono w nim uwagę na dyskusyjne parametry tego ubezpieczenia, tj. zakres ochrony ubezpieczeniowej, pole ubezpieczeniowe, sumę gwarancyjną, składkę i koszty likwidacji. Ubezpieczenie obowiązkowe odpowiedzialności cywilnej pośredników kredytu hipotecznego jest nowym produktem na rynku ubezpieczeń, chroniącym kolejną grupę zaufania społecznego.

Słowa kluczowe: pośrednicy kredytu hipotecznego, ubezpieczenie odpowiedzialności cywilnej, ryzyko.

Summary: The financial crisis of years 2007-2009 led to important actions (through appropriate directives) aimed at protecting the consumer as the weaker side to the loan agreement. On the mortgage loan intermediaries, apart from many requirements, an obligation to conclude a liability insurance contract was imposed. The article focuses on the debatable parameters of this insurance, i.e. the scope of insurance coverage, guarantee sum, premium and liquidation costs. Compulsory insurance of liability of mortgage loan intermediary is a new product on the insurance market that protects another group of social trust.

Keywords: mortgage loan intermediary, liability insurance, risk. 


\section{Wstęp}

Kryzys finansowy z lat 2007-2009 doprowadził do tego, że należy zapewnić bezpieczeństwo finansowe przy udzielaniu kredytów hipotecznych. Pokazał on także, że nieodpowiedzialne zachowanie uczestników rynku może naruszyć podstawy systemu finansowego, tworząc zjawisko braku zaufania między jednostkami udzielającymi kredytów a konsumentami. W związku z tym grupa G-20 zaleciła Radzie Stabilności Finansowej opracowanie odpowiednich standardów zawierania umów o kredyt hipoteczny m.in. na cele mieszkaniowe. Wiadome jest, że konsument na rynku finansowym jest stroną słabszą, zatem powinien posiadać odpowiednią ochronę. W rezultacie w 2014 r. powstała tzw. dyrektywa hipoteczna (MCD - Mortgage Credit Directive $)^{1}$, która m.in. miała na celu ustosunkowanie się do nieodpowiedzialnego zachowania się uczestników rynku, w tym pośredników kredytowych i instytucji niekredytowych świadczących usługi w zakresie udzielania kredytów hipotecznych w walutach obcych. Dyrektywa hipoteczna nakłada obowiązek m.in. na pośredników kredytu hipotecznego posiadania odpowiednich uprawnień, udzielania rzetelnej wiedzy i informacji, kompetencji i odpowiedzialności przy zawieraniu umów o kredyt hipoteczny.

Stosowanie standardów jakości usług obejmujących udzielanie kredytów poskutkowało w Polsce pojawieniem się stosownych przepisów. Kwestia pośrednictwa kredytowego została szczegółowo uregulowana w Ustawie z dnia 12 maja 2011 roku o kredycie konsumenckim (tekst jednolity Dz.U. 2016, poz. 1528, 2017, poz. 819), stanowiąc implementację dyrektywy w sprawie umów o kredyt konsumencki (CCD - Consumer Credit Directive). Przepisy tej ustawy w pewnym sensie nawiązują do problematyki kredytów hipotecznych ${ }^{2}$.

W dniu 21 marca 2017 roku ukazała się ustawa o kredycie hipotecznym oraz nadzorze nad pośrednikami kredytu hipotecznego i agentami (Dz.U. 2017, poz. 819).

1 The Mortgage Credit Directive 2014/17/EU (MCD) [The Mortgage Credit Directive 2014/17/ EU...] pierwotnie została przyjęta przez Komisję Europejską 4 lutego 2014 r., a państwa członkowskie musiały dokonać transpozycji przepisów do prawa krajowego do marca 2016 r. Dyrektywa wprowadza europejskie ramy norm postępowania dla firm sprzedających kredyty hipoteczne na cele mieszkaniowe. Celem dyrektywy jest stworzenie ogólnounijnego rynku kredytów hipotecznych o wysokim poziomie ochrony konsumentów.

2 Zgodnie z ustawą o kredycie konsumenckim, art. 3.1: „Przez umowę o kredyt konsumencki rozumie się umowę o kredyt w wysokości nie większej niż 255550 zł albo równowartość tej kwoty w walucie innej niż waluta polska, który kredytodawca w zakresie swojej działalności udziela lub daje przyrzeczenie udzielenia konsumentowi”; 1a: „Przez umowę o kredyt konsumencki rozumie się także umowę o kredyt niezabezpieczony hipoteką, który jest przeznaczony na remont domu albo lokalu mieszkalnego, w tym w wysokości większej niż wysokość określona w ust. 1". Wynika z tego, że przepisy te nie dotyczą kredytów zabezpieczonych hipoteką o wyższych kwotach, a przeznaczone na budowę domu czy kupno mieszkania. Ponadto zgodnie z art. 4.1 pkt 7: „Ustawy nie stosuje się do umów: odwróconego kredytu hipotecznego zawartych na podstawie ustawy z dnia 23 października 2014 r. o odwróconym kredycie hipotecznym (Dz.U. 2016, poz. 786)". 
Na podstawie tej ustawy, na mocy art. 55 ust. 3, wprowadzono obowiązek ubezpieczenia odpowiedzialności cywilnej (OC) pośrednika kredytu hipotecznego.

Brak regulacji prawnych pośrednictwa kredytowego w Polsce stanowił zagrożenia dla rozwoju rynku finansowego. Mogło się zdarzyć, że realizacje usług pośrednictwa kredytów hipotecznych prowadzone były przez osoby nieposiadające odpowiedniej wiedzy i kompetencji. Rozporządzeniem Prezesa Rady Ministrów z dnia 3 października 2017 roku w sprawie wpłat na pokrycie kosztów nadzoru nad pośrednikami kredytu hipotecznego (Dz.U. 2017, poz. 1914) objęta została kolejna ważna grupa społeczna funkcjonująca na rynku nieruchomości.

Celem artykułu jest wieloaspektowa ocena wprowadzenia nowego obowiązkowego produktu ubezpieczeniowego, jakim jest obowiązkowe ubezpieczenie odpowiedzialności cywilnej (OC) pośrednika kredytu hipotecznego. W artykule obszernie omówiono nowy produkt pod względem wybranych parametrów, istotnych dla rynku ubezpieczeniowego.

\section{Rodzaje ryzyka towarzyszące zawieraniu umów kredytów hipotecznych}

W języku potocznym wszystkie kredyty związane z finansowaniem zakupu domu lub mieszkania albo ich remontem nazywane są kredytami hipotecznymi ${ }^{3}$. Tymczasem, zgodnie z ustawą o kredycie hipotecznym oraz nadzorze nad pośrednikami kredytu hipotecznego i agentami, art. 3. 1 pkt. 1-4: „Przez umowę o kredyt hipoteczny rozumie się umowę, w ramach której kredytodawca udziela konsumentowi kredytu lub daje mu przyrzeczenie udzielenia kredytu zabezpieczonego hipoteką lub innym prawem związanym z nieruchomością mieszkalną lub przeznaczonego na sfinansowanie niezwiązanego z działalnością gospodarczą lub prowadzeniem gospodarstwa rolnego nabycia lub utrzymania: prawa własności budynku mieszkalnego lub lokalu mieszkalnego stanowiącego odrębną nieruchomość, a także ich budowy lub przebudowy (...); spółdzielczego własnościowego prawa do lokalu; prawa własności nieruchomości gruntowej lub jej części; udziału we współwłasności budynku mieszkalnego lub lokalu mieszkalnego stanowiącego odrębną nieruchomość lub udziału w nieruchomości gruntowej”. Z kolei KNF w Rekomendacji S ${ }^{4}$ określa, że celem podstawowym (dominującym) ekspozycji kredytowej finansującej nieruchomość jest finansowanie nabycia, budowy, przebudowy, nadbudowy, wykończenia, modernizacji, adaptacji lub remontu nieruchomości. Natomiast ekspozycja kredytowa zabezpieczona hipotecznie oznacza ekspozycję kredytową, w przypadku której zostało już ustanowione zabezpieczenie w postaci hipoteki lub zabezpieczenie takie stanowi zabezpieczenie docelowe.

${ }^{3}$ Kredyty hipoteczne są zabezpieczone hipoteką na nieruchomości czy prawach, niekoniecznie związanych z celem kredytu, np. budowlanym. Natomiast nie wszystkie kredyty związane z nabyciem praw własności albo stanu nieruchomości (w wyniku remontu, przebudowy) są kredytami hipotecznymi.

${ }^{4}$ Zobacz [Komisja Nadzoru Finansowego, słowniczek pojęć - nr 6-7]. 
Przez pojęcie kredytu hipotecznego należy rozumieć udzielanie środków finansowych przez banki na sfinansowanie zakupu nieruchomości lub realizację inwestycji budowlanej na rynku nieruchomości mieszkaniowych ${ }^{5}$. Są to kredyty długoterminowe od 3-25 lat ${ }^{6}$, w których zabezpieczeniem jest hipoteka na nieruchomości. Warunkiem ich otrzymania jest posiadanie m.in. wkładu własnego - min. 20\%. Kredyt oprocentowany jest na ogół zmienną stopą procentową, np. WIBOR3M, powiększoną o marżę banku, i może być spłacany z ustaloną częstotliwością, np. co miesiąc. Stopa procentowa może być stała w ustalonym w umowie okresie. Ponadto banki mogą obciążać kredytobiorcę dodatkowymi kosztami, np. prowizją, opłatą wstępną za przyjęcie i rozpatrzenie wniosku kredytowego, za udzielenie kredytu, kosztami wyceny nieruchomości itp.

Podobnie jak przy zawieraniu innych umów kredytowych, także i w przypadku kredytów hipotecznych występują różne rodzaje ryzyka, np.:

- ryzyko spłaty kredytu ${ }^{7}$, ponieważ z jednej strony jest to kredyt wieloletni, a z drugiej strony dynamiczna sytuacja majątkowa kredytobiorców może powodować zakłócenia w regularnych spłatach rat kredytu; dlatego też kredyt hipoteczny wymaga ochrony ubezpieczeniowej [Staniewski 2008, s. 45-47]; długi okres spłaty i losowe negatywne zdarzenia dotykające kredytobiorców mogą spowodować realizację ryzyka spłaty kredytu, które może zostać przejęte przez zakład ubezpieczeń, pod warunkiem że kredytobiorca przystąpił wcześniej do odpowiedniego ubezpieczenia, np. ubezpieczenia na życie kredytobiorcy;

- ryzyko zabezpieczenia, polegające na tym, że przyjęte przez bank zabezpieczenie nie zapewnia w pełni zwrotu zaangażowanego kapitału wraz z odsetkami i prowizjami; przy tym wiele kredytów hipotecznych jest tylko teoretycznie zabezpieczonych, ponieważ wartość salda zadłużenia jest wyższa od aktualnej wyceny rynkowej nieruchomości [Mędrała 2012, s. 31]; dotyczy to w szczególności umów kredytowych zawartych przed kryzysem finansowym, ponieważ obecnie maksymalny ustalany przez bank poziom wskaźnika $\mathrm{LtV}^{8}$ nie powinien być wyższy niż $80 \%$ dla ekspozycji o pierwotnym okresie spłaty powyżej 5 lat i $90 \%$ dla pozostałych ekspozycji [Komisja Nadzoru Finansowego, pkt 4.6.7]; istnieje ponadto zagrożenie, że gdy bank nie zaspokoi swoich wierzytelności poprzez windykację nieruchomości, sięgnie on po inne składniki majątkowe kredytobiorcy; z ryzykiem tym związane jest także ryzyko zmiany koniunktury na rynku nieruchomości, gdyż spadek cen nieruchomości będzie skutkował niższą wartością zabezpieczenia kredytu;

${ }^{5}$ Kredyt hipoteczny został zdefiniowany w literaturze przedmiotu przez licznych autorów, m.in. w takich pracach, jak: [Główka 2008, s. 45; Kalasińska 2010, s. 35; Kowalczyk-Rólczyńska 2015, s. 43].

${ }_{6}$ 25-letni okres spłaty kredytu jest okresem rekomendowanym przez KNF, zgodnie z zapisami Rekomendacji S (Rekomendacja 7.1).

${ }^{7}$ Nazywane także ryzykiem kredytowym.

${ }^{8}$ Wskaźnik LtV wyraża stosunek wartości ekspozycji kredytowej do wartości zabezpieczenia. 
- ryzyko walutowe, które realizuje się w sytuacji zmieniających się kursów walutowych dla zadłużeń w walucie obcej, a jest minimalizowane przez banki w szczególności poprzez zapewnienie zgodności waluty ekspozycji i przychodów, z których będzie spłacana [Komisja Nadzoru Finansowego, Rekomendacja, pkt 3.1.1];

- ryzyko stopy procentowej, które w sytuacji wzrostu stóp procentowych skutkuje wyższym kosztem kredytu, a tym samym zwiększeniem rat kredytowych (na skutek wzrostu raty odsetkowej).

16 października 2017 roku ukazało się Rozporządzenie Prezesa Rady Ministrów z dnia 3 października 2017 roku w sprawie wpłat na pokrycie kosztów nadzoru nad pośrednikami kredytu hipotecznego (Dz.U. 2017, poz. 1914). Rozporządzenie to określa:

- terminy wnoszenia, wysokość i sposób obliczenia wpłat na poczet pokrycia kosztów nadzoru nad pośrednikami kredytu hipotecznego,

- sposób i terminy rozliczania należności z tytułu wpłat na pokrycie kosztów nadzoru.

Warto także podkreślić, że zakłady ubezpieczeń odpowiadają za negatywne losowe zdarzenia, które mogą powstać w czasie zawierania przez pośrednika kredytu hipotecznego. Definicja zdarzenia losowego jest sprecyzowana w art. 3 ustawy o działalności ubezpieczeniowej i reasekuracyjnej [Ustawa z dnia 11 września 2015 r. ....].

Warto przypomnieć, że na banki ustawowo nałożono obowiązek informacyjny ${ }^{9}$ wraz z rozszerzonymi rekomendacjami KNF, według którego konsument ma być szczegółowo poinformowany o warunkach kredytu (w tym wszelkich kosztach - zasadach oprocentowania, pobierania prowizji i opłat - od zawarcia umowy i jego spłaty terminowej lub przedterminowej, o kosztach opóźnień w spłacie kredytu, zmian warunków kredytowych, wypowiedzenia czy też niewykorzystania części kredytu).

Kilka metod kalkulacji rat kredytu hipotecznego przy ustalonym oprocentowaniu opłat według długości okresu spłaty zaprezentował Piotr Rybicki [2017]. Przedstawił on ponadto sposób wyboru mieszkania, listę banków, konstrukcję wniosku kredytowego oraz liczne uwagi praktyczne. Jest to uproszczona wersja obliczeniowa.

\section{Przedmiot ubezpieczenia}

Przedmiotem ubezpieczenia jest odpowiedzialność cywilna pośrednika kredytu hipotecznego, która dotyczy umowy deliktowej. Chodzi tu o pośredników kredytu hipotecznego objętych obowiązkową ochroną ubezpieczeniową z chwilą wejścia w życie analizowanego rozporządzenia. Dotyczy to obecnych pośredników kredytu

\footnotetext{
9 Por. [Ustawa z dnia 29 sierpnia 1997 roku..., art. 76-79, 101, 110-111].
} 
hipotecznego, a także osób, które będą w przyszłości wykonywać te zadania ${ }^{10}$. Jak należy przypuszczać, rozporządzenie dotyczyć będzie wyłącznie osób, które zajmują się pośrednictwem w zawieraniu umów kredytów hipotecznych.

W ustawie o kredycie hipotecznym oraz nadzorze nad pośrednikami kredytu hipotecznego [Ustawa z dnia 25 marca 2017 roku...] zdefiniowane zostały takie pojęcia, jak:

- Pośrednik kredytu hipotecznego - przedsiębiorca w rozumieniu art. 43 ustawy z dnia 23 kwietnia 1964 roku - Kodeks cywilny niebędący kredytodawcą, który w ramach wykonywanej działalności gospodarczej lub zawodowej za wynagrodzeniem w formie pieniężnej lub innej uzgodnionej formie korzyści finansowej:

- przedstawia lub oferuje konsumentom umowy o kredyt hipoteczny lub,

- udziela konsumentom pomocy, podejmując prace przygotowawcze lub inne przedumowne działania administracyjne inne niż wymienione, polegające na obsłudze dokumentów w związku z umowami o kredyt hipoteczny,

- lub zawiera z konsumentami umowy o kredyt hipoteczny w imieniu kredytodawcy.

- Powiązany pośrednik kredytu hipotecznego - pośrednik hipoteczny, który działa w imieniu i na rzecz:

wyłącznie jednego kredytodawcy;

- wyłącznie jednej grupy kredytodawców, którzy podlegają konsolidacji do celów sporządzania skonsolidowanych sprawozdań finansowych,

- określonej liczby kredytobiorców lub grupy kredytodawców, które nie stanowią co najmniej połowy liczby kredytodawców funkcjonujących na rynku świadczonych w zakresie udzielania kredytów hipotecznych.

Zgodnie z ustawą o kredycie konsumenckim pośrednikiem kredytowym może być przedsiębiorca, który zawodowo dokonuje czynności faktycznych lub prawnych związanych z przygotowaniem, oferowaniem lub zawieraniem umowy o kredyt. Pośrednik działa odpłatnie i na niego nałożono odpowiedzialne obowiązki informacyjne dla kredytobiorców na każdym etapie relacji konsument-pośrednik kredytowy. Pośrednikiem kredytu hipotecznego może być osoba, która:

- posiada zdolności do czynności prawnych,

- nie była karana m.in. w obrocie finansowym,

- ma wykształcenie minimum średnie,

- zdała pozytywnie egzaminy przed Komisją KNF,

- złożyła oświadczenie o zawarciu umowy ubezpieczenia odpowiedzialności cywilnej.

Artykuł 7.1 ustawy o kredycie hipotecznym stanowi, że kredytodawca, pośrednik kredytu hipotecznego w reklamie dotyczącej kredytu hipotecznego są zobowiązani:

${ }_{10}$ Jak wiadomo, każdy agent i broker ubezpieczeniowy już posiada obowiązkowe ubezpieczenie odpowiedzialności cywilnej. 
- zapewnić, aby wszelkie informacje o charakterze reklamowym i marketingowym dotyczące kredytów hipotecznych były jednoznaczne, rzetelne, zrozumiałe i widoczne oraz nie wprowadzały konsumenta w błąd;

- nie stosować dwuznacznych i nieprecyzyjnych sformułowań mogących stwarzać u konsumenta fałszywe oczekiwania w zakresie dostępności lub całkowitego kosztu kredytu hipotecznego;

- zapewnić, aby czcionka oraz czas, w jakim są wyświetlane wszelkie informacje o charakterze reklamowym i marketingowym, umożliwiały odczytanie tych informacji przez konsumenta.

Ponadto informacje, podane w sposób zwięzły, jednoznaczny, zrozumiały i widoczny, powinny zawierać następujące parametry: opłaty, koszt kredytu, wysokość stopy procentowej.

Każdy pośrednik ubezpieczeniowy, w tym pośrednik kredytu hipotecznego, powinien doskonalić wiedzę dotyczącą obszaru zajmowanego zawodowo. Jest to wymóg nie tylko obrony przed wypaleniem zawodowym, ale i wymóg prawny ${ }^{11}$. Podobnie każdy (pośrednik) pracownik oferujący kredyty hipoteczne będzie musiał przejść cykl szkoleń i testów, a jego wynagrodzenie ma zależeć nie tylko od osiągnięcia celów sprzedażowych, ale również od jakości pracy weryfikowanej na podstawie liczby reklamacji.

Pośrednicy kredytowi podlegają kontroli Komisji Nadzoru Finansowego (zakres tej kontroli jest bardzo szczegółowy). Są oni zarejestrowani i mogą prowadzić działalność po spełnieniu wszystkich warunków.

\section{Pole ubezpieczeniowe, wymóg obowiązkowości ubezpieczenia OC pośrednika kredytowego hipotecznego}

Przez pojęcie pola ubezpieczeniowego rozumie się maksymalną liczbę podmiotów możliwych do ubezpieczenia według stanu na dzień oceny ryzyka ubezpieczeniowego. W naszym przypadku chodzi o liczbę zarejestrowanych pośredników kredytu hipotecznego i agentów na ich rzecz pracujących. Liczba tych osób będzie zależna od sytuacji na rynku kredytów mieszkaniowych (hipotecznych). Została ona omówiona w dalszej części tekstu.

W 2016 r. dynamika akcji kredytowej była dodatnia i stabilna. Niskie stopy procentowe złotowych kredytów mieszkaniowych oraz wzrost realnych dochodów gospodarstw domowych miały pozytywny wpływ na ich zdolność kredytową. Saldo należności od gospodarstw domowych z tytułu kredytów mieszkaniowych w grudniu wyniosło 394,3 mld zł, tj. wzrosło o 18,7 mld zł w porównaniu z 2015 rokiem. Wysoki popyt na mieszkania był konsekwencją wzrostu wynagrodzeń gospodarstw domowych, utrzymywania się historycznie niskich nominalnych stóp procentowych (zarówno depozytów, jak i kredytów), obowiązywania programu subsydiów Miesz-

${ }^{11}$ Porównaj m.in. [Rozporządzenie Ministra Finansów z dnia 7 lipca 2005 roku...]. 
kanie dla Młodych (MDM) oraz zapowiedzi braku jego kontynuacji po 2018 roku. W konsekwencji obserwowano przyspieszenie zakupów mieszkań deweloperskich dla celów własnych oraz inwestycyjnych [Łaszek (red.) 2017, s. 7].

Jak wynika z raportów NBP, w ostatnich dwunastu latach sukcesywnie wzrastała nominalna wartość kredytów mieszkaniowych udzielonych gospodarstwom domowym (z 59,2 mld zł w 2005 roku [NBP 2006, s. 72] do 391 mld zł w roku 2016 [NBP 2017, s. 101]), przy czym od roku 2008 (rys. 1) zdecydowanie zwiększał się udział kredytów złotowych w strukturze walutowej kredytów mieszkaniowych. $\mathrm{Na}$ tę sytuację istotny wpływ miała wprowadzona Rekomendacja S, zgodnie z którą od 1 lipca 2014 roku waluta ekspozycji kredytowej nie może być inna od waluty osiąganego dochodu przez kredytobiorców.

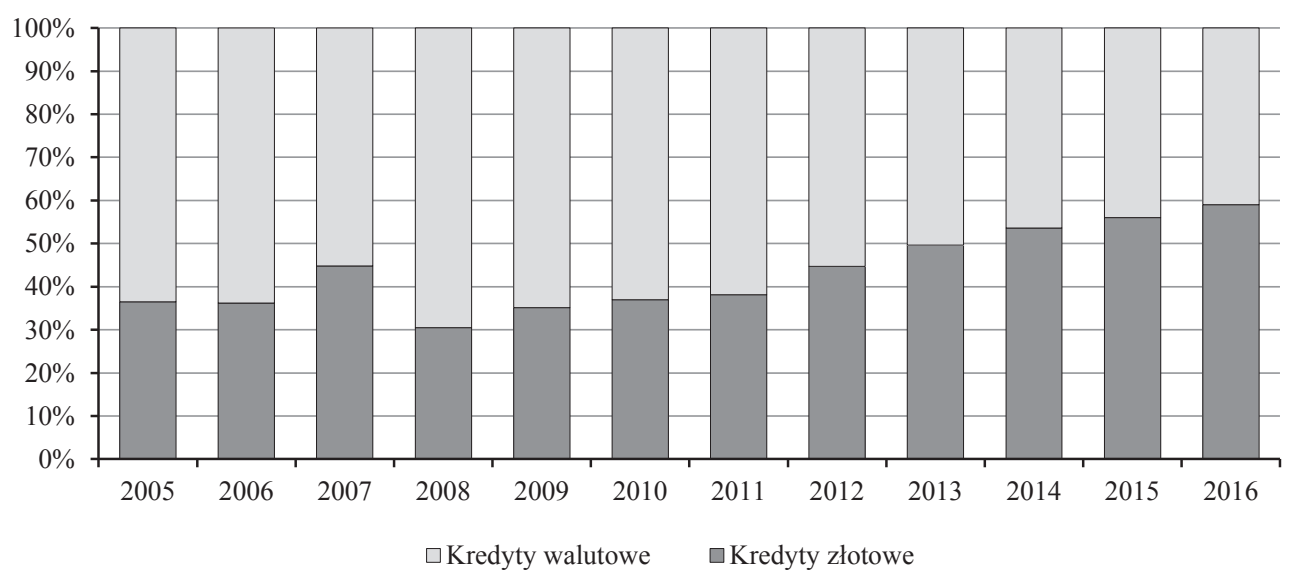

Rys. 1. Struktura walutowa kredytów mieszkaniowych dla gospodarstw domowych w latach 2005-2016 Źródło: opracowanie własne na podstawie danych z raportów NBP [Rozwój systemu finansowego w Polsce, http://www.nbp.pl/home.aspx?f=/systemfinansowy/rozwoj.html (21.02.2018)].

O rozwoju rynku kredytów mieszkaniowych świadczą także rosnąca liczba czynnych umów o kredyt mieszkaniowy, przedstawiona na rys. 2, oraz zwiększający się niemal w całym okresie stan zadłużenia z tytułu kredytów mieszkaniowych. Należy zaznaczyć, iż malejąca wartość średniego oprocentowania kredytu mieszkaniowego w latach 2009-2014 (a w ostatnim okresie utrzymująca się na zbliżonym poziomie) sprzyjała i nadal może sprzyjać wykorzystaniu kredytu mieszkaniowego do sfinansowania zakupu nieruchomości mieszkaniowej. Warto jeszcze dodać, iż średnia wartość jednego kredytu, według najnowszych dostępnych danych na koniec III kw. 2017 roku, wyniosła blisko 239 tys. zł [Amron Sarfin]. Natomiast wartość portfela kredytów mieszkaniowych w poszczególnych bankach na koniec 2016 roku w mld zł była następująca: PKO BP $(101,4)$, Pekao $(46,2)$, mBank $(37,7)$, Millennium $(27,8)$, ING BSK $(23,3)$. 


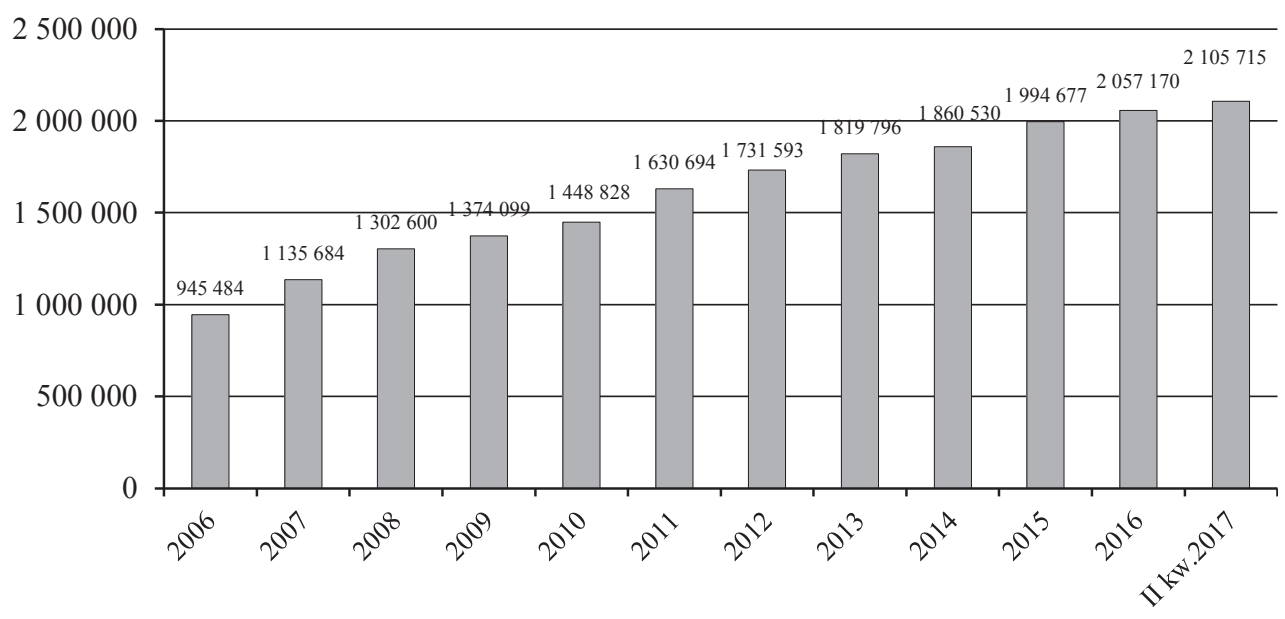

Rys. 2. Liczba czynnych umów o kredyt mieszkaniowy w okresie 2006-II kw. 2017

Źródło: opracowanie własne na podstawie danych z raportów Amron Sarfin [Amron Sarfin].

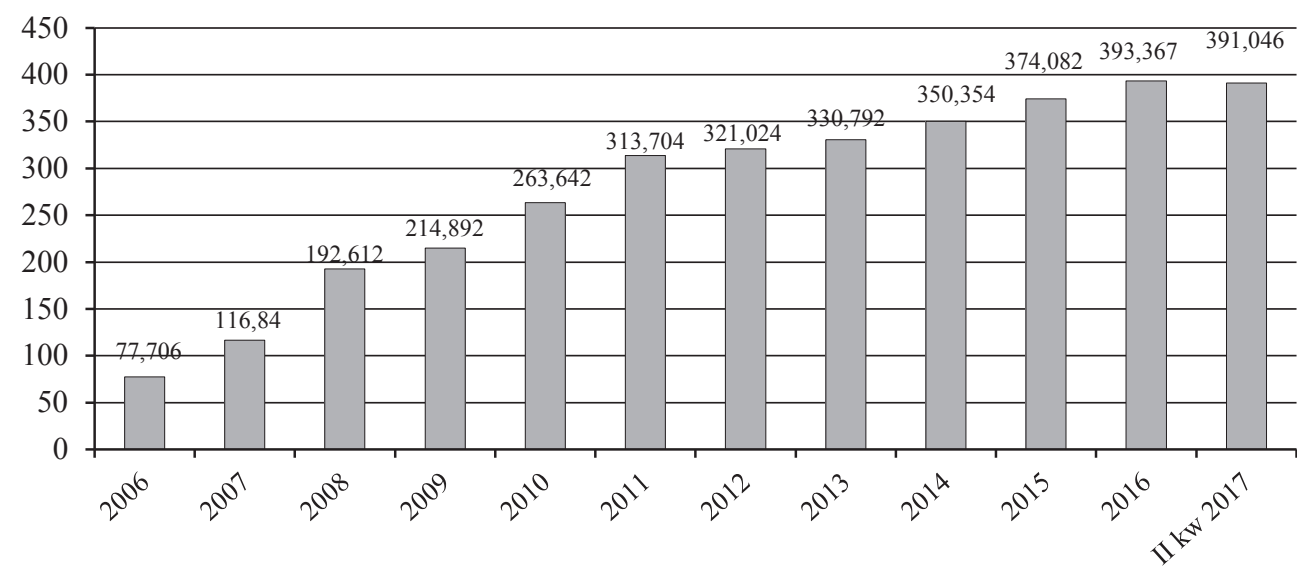

Rys. 3. Całkowity stan zadłużenia z tytułu kredytów mieszkaniowych w mld zł w okresie 2006-II kw. 2017

Źródło: opracowanie własne na podstawie danych z raportów Amron Sarfin [Amron Sarfin].

Dane GUS i ZBP z lat 2006-2016 wskazują na rosnącą rolę pośrednictwa kredytowego. W tym okresie udział pośredników w sprzedaży kredytów hipotecznych podwoił się - z ok. 20\% w 2006 roku do 45\% w roku 2016 [Waliszewski 2017, s. 8].

Na podstawie danych Ministerstwa Finansów (dane za 2014 roku) szacuje się, że rocznie ok. 250 tys. osób fizycznych zawiera umowy o kredyt hipoteczny [Słowik 201, s. B6]. Z kolei z ogólnopolskiego raportu o kredytach mieszkaniowych (stan na z 1 kwietnia 2017 roku) wynika, że w III kw. 2017 roku [Amron Sarfin]: 
- Średnia wartość udzielonego kredytu w PLN wynosiła 237 454, natomiast średnia wartość kredytu denominowanego w walutach obcych - 346760 zł;

- wartość Indeksu Dostępności Mieszkaniowej ${ }^{12} \mathrm{M}_{3}$ wyniosła 196,76 pkt;

- udział nowo udzielonych kredytów mieszkaniowych z LTV na poziomie co najmniej $80 \%$ wyniósł 46,89\%;

- udział kredytów o okresie zapadalności 25-35 lat w strukturze nowych umów kredytowych wynosił $63,20 \%$, natomiast udział o okresie zapadalności 15-25 lat $-24,89 \%$;

- największą popularnością cieszyły się (podobnie jak w poprzednich okresach) kredyty o wartości między 100 a 200 tys. zł, stanowiące 35\% portfela nowych umów kredytowych.

21 lipca 2017 roku ukazało się Rozporządzenie Ministra Rozwoju i Finansów w sprawie obowiązkowego ubezpieczenia odpowiedzialności cywilnej pośrednika kredytu hipotecznego (Dz.U. 2017, poz. 1403). Rozporządzenie nadaje charakter obowiązkowego ubezpieczenia odpowiedzialności cywilnej. Fakt ten interpretować można następująco:

- wszyscy pośrednicy kredytu hipotecznego muszą posiadać ubezpieczenie odpowiedzialności cywilnej i zapłacić odpowiednią roczną składkę ubezpieczeniową (jednorazowo lub w ratach);

- brak tego ubezpieczenia będzie skutkował karą lub wykreśleniem z rejestru;

- obowiązek dotyczy pośredników kredytu hipotecznego działających na terenie Polski i nie wyklucza on pośredników w strefie transgranicznej;

- nie zostały sprecyzowane zasady kontroli posiadania opisywanego ubezpieczenia.

Z punktu widzenia społecznego można stwierdzić, że ten produkt ubezpieczeniowy obejmuje ochroną ubezpieczeniową kolejną grupę zaufania społecznego. Przyjęcie obowiązkowego ubezpieczenia powoduje, że ciężar ewentualnych strat spowodowanych przez pośredników kredytu hipotecznego rozłożony jest na wszystkie podmioty ubezpieczane. Oznacza to również, że składka ubezpieczeniowa nie powinna być wygórowana. Ochrona ubezpieczeniowa dla tej grupy społecznej może być przyjęta nie tylko przez komercyjne zakłady ubezpieczeń, ale i przez towarzystwa ubezpieczeń wzajemnych.

Obowiązkowy charakter powoduje, że ryzyko ubezpieczeniowe jest jednorazowo rozłożone na wszystkich ubezpieczonych. Zakład ubezpieczeń (TUW) może objąć ochroną ubezpieczeniową całość lub dowolny podzbiór pośredników kredytu hipotecznego. Umowy ubezpieczeniowe mogą być roczne z możliwością ich corocznego wznowienia przy uzgodnionych ich parametrach.

Wadą tego ubezpieczenia jest obowiązek ubezpieczenia, który należy spełnić bez względu na podatność pośredników kredytu hipotecznego na możliwość powstania szkody. Warto zwrócić uwagę, że w sensie fizycznym pośrednikami kredytu

${ }^{12}$ Indeks Dostępności Mieszkaniowej (IDM) M3 pokazuje kwartalne zmiany w dostępności mieszkania dla przykładowej rodziny składającej się z dwóch pracujących osób i dziecka starszego. 
hipotecznego mogą być osoby pracujące np. w bankach (spełniające warunki bycia pośrednikami), doradcy inwestycyjni. Pośrednicy ubezpieczenia kredytu hipotecznego powinni być przeszkoleni przez specjalistów, nim przystąpią do zawierania ubezpieczeń.

Z punktu widzenia ekonomiki ubezpieczeń korzystne dla obu stron są umowy ubezpieczenia, gdy jest masowość podpisanych kontraktów ubezpieczeniowych. Scharakteryzowane pole ubezpieczeniowe spełnia warunki masowości, co powoduje, że składka ubezpieczeniowa powinna być przystępna dla klientów.

\section{Zakres odpowiedzialności ubezpieczenia i jego ograniczenia}

Ważnym elementem ubezpieczenia obowiązkowego OC pośrednika kredytu hipotecznego jest określenie jego odpowiedzialności. Pośrednik kredytu hipotecznego zawiera szereg umów, np. w ciągu roku, z klientami zaciągającymi kredyt hipoteczny.

Rozporządzenie §2.1 stanowi, że ubezpieczeniem objęta jest odpowiedzialność cywilna pośrednika kredytu hipotecznego za „szkody wyrządzone działaniem lub zaniechaniem ubezpieczonego $\mathrm{w}$ okresie ubezpieczenia $\mathrm{w}$ związku $\mathrm{z}$ wykonywaną działalnością w zakresie pośrednictwa kredytu hipotecznego". Z kolei w $§ 2.2$ tego Rozporządzenia doprecyzowuje się, że „ubezpieczeniem OC są objęte również szkody wyrządzone przez agenta danego pośrednika kredytu hipotecznego w związku z wykonywaniem działalności w zakresie pośrednictwa kredytu hipotecznego". Te dwa podpunkty jednoznacznie wskazują na odpowiedzialność cywilną pośrednika kredytu hipotecznego i jego agenta (współpracownika). Rozporządzenie odnosi się do jednego agenta danego pośrednika kredytu hipotecznego, co w praktyce może oznaczać, że na rzecz pośrednika kredytu hipotecznego może pracować kilku agentów. Rozporządzenie w $§ 2.1$ stanowi, że pośrednik kredytu hipotecznego odpowiada za "szkody wyrządzone działaniem lub zaniechaniem ubezpieczonego", nie precyzując tych pojęć. Są to pojęcia wieloznaczne.

Z zakresu odpowiedzialności pośrednika kredytu hipotecznego i jego agenta (agentów) wyłączone zostały następujące szkody ( 2 p. 3):

- polegające na uszkodzeniu, zniszczeniu lub utracie mienia wyrządzonych przez ubezpieczonego małżonkowi, wstępnemu, zstępnemu, rodzeństwu, a także powinowatemu w tej samej linii lub stopniu, osobie pozostającej w stosunku przysposobienia oraz jej małżonkowi, jak również osobie, z którą ubezpieczony lub agent danego pośrednika kredytu hipotecznego pozostaje we wspólnym pożyciu;

- wyrządzonych przez ubezpieczonego lub agenta danego pośrednika kredytu hipotecznego po wykreśleniu z rejestru pośredników kredytowych, chyba że szkoda jest następstwem wykonywania działalności w zakresie pośrednictwa kredytu hipotecznego przed wykreśleniem z rejestru pośredników kredytowych,

- polegających na zapłacie kar umownych powstałych wskutek działań wojennych, rozruchów i zamieszek, a także aktów terroru. 
Te wyłączenia (ich katalog) z zakresu OC pośrednika kredytu hipotecznego i agenta obejmują szkody powstałe na osobach najbliższych dla zawierającego umowę kredytu hipotecznego, a także w sytuacjach kryzysowych i ekstremalnych. Pominięta została wina umyślna pośrednika kredytu hipotecznego i jego agenta. Pominięto również odpowiedzialność cywilną powstałą w czasie strajków, stanu wojennego.

Warto także zwrócić uwagę, że ustawodawca w §2 pkt 4 nie dopuszcza, aby zakład ubezpieczeń dokonywał jakichkolwiek ,umownych ograniczeń odpowiedzialności”, co można interpretować następująco:

- zakład ubezpieczeń ponosi pełną odpowiedzialność za powstałe szkody,

- nie można stosować franszyzy czy też udziałów własnych przy konstrukcji szczegółowych warunków ubezpieczeń, a także taryf ubezpieczeniowych.

W ograniczeniach odpowiedzialności ustawodawca pomija także szkody powstałe z tytułu rażącego niedbalstwa pośrednika kredytu hipotecznego.

Jak należy domniemać, wprowadzone ubezpieczenie odpowiedzialności cywilnej pośrednika kredytu hipotecznego będzie zawierane na okres jednego roku. Można je zakwalifikować do ubezpieczeń działu II, które zostały określone w załączniku do ustawy o działalności ubezpieczeniowej i reasekuracyjnej.

\section{Suma gwarancyjna}

Ważny parametr w obowiązkowych ubezpieczeniach odpowiedzialności cywilnej zajmuje określenie granic finansowej odpowiedzialności zakładu ubezpieczeń chroniących podmiot ubezpieczony. Granicę odpowiedzialności finansowej zakładu ubezpieczeń określa suma gwarancyjna. Jest to kwota określona przez ustawodawcę w jednostkach pieniężnych, stanowiąca górną granicę odpowiedzialności zakładu ubezpieczeń. W analizowanym rozporządzeniu w $\$ 4.1$ podjęto decyzję o „minimalnej sumie gwarancyjnej ubezpieczenia OC w okresie nie dłuższym niż 12 miesięcy wynoszącej równowartość 460000 euro w odniesieniu do jednego zdarzenia, którego skutki są objęte umową ubezpieczenia OC, oraz 750000 w odniesieniu do wszystkich takich zdarzeń”. W paragrafie 4.2 doprecyzowuje się zasady przeliczenia kursu euro na złotówki. Jak łatwo zauważyć, rozporządzenie ustala minimalną sumę gwarancyjną dla omawianego ubezpieczenia OC pośrednika kredytu hipotecznego. Górna granica odpowiedzialności nie została sprecyzowana i może być większa niż minimalna. Górne granice sum gwarancyjnych mogą być ustalone przez zakład ubezpieczeń w przypadkach:

- własnej oceny ryzyka funkcjonowania w praktyce pośredników kredytu hipotecznego,

- po kilku latach doświadczeń funkcjonowania omawianego ubezpieczenia.

Ustalenia w $\$ 4.1$ można ująć na hipotetycznym rys. 4. Zakład ubezpieczeń, zawierając umowy ubezpieczenia na minimalne sumy gwarancyjne, nie może wypłacić łącznie za jedną szkodę czy wszystkie szkody powstałe roszczenia w okresie ubezpieczenia na kwotę większą niż ich przyjęta wysokość. 


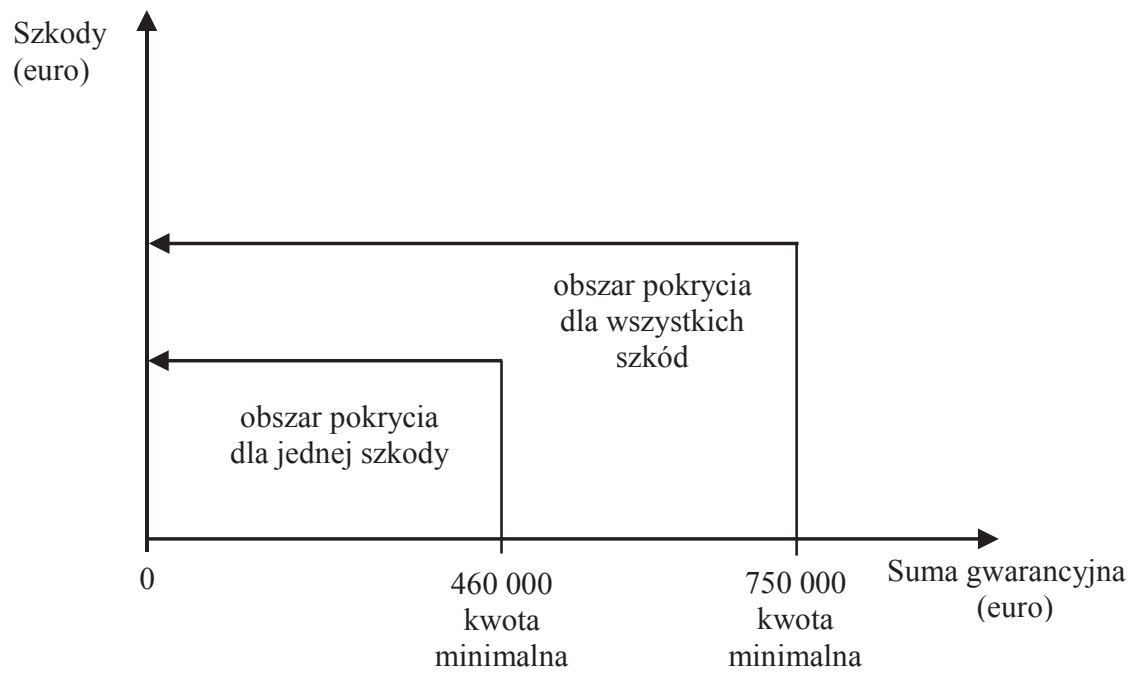

Rys. 4. Obszary pokrycia szkód

Źródło: opracowanie własne.

Jak należy domniemywać, suma kwot szkód przekraczających minimalne sumy gwarancyjne będzie obciążać sprawcę szkody. Dyskusyjna jest wysokość minimalnych sum gwarancyjnych podana przez ustawodawcę. Ustawodawca nie określa sposobów i zasad ich wyliczenia. Nie został doprecyzowany okres odpowiedzialności zakładu ubezpieczeń. Wiadomo, że muszą powstać (i musi być udowodnione ich powstanie) w „okresie ubezpieczenia” (\$2.1). W tym miejscu rozporządzenie nie precyzuje czasu zgłoszenia szkody i jej ujawnienia.

W przypadku sumy gwarancyjnej w literaturze rozważana jest: kolejność wypłat dla poszkodowanych, czas oczekiwania na realizację roszczeń, wyczerpywalność, liczba poszkodowanych. Ponadto suma gwarancyjna jest parametrem finansowym w umowie ubezpieczenia. Minimalna suma gwarancyjna uwarunkowuje minimalną składkę przypisaną dla ubezpieczyciela.

\section{Składka ubezpieczeniowa}

Bardzo ważnym elementem każdej umowy ubezpieczenia jest policzenie składki ubezpieczeniowej. Podstawą do obliczenia składki ubezpieczeniowej jest sprecyzowany zakres ochrony ubezpieczeniowej. W paragrafach 2.1 i 2.2 Ustawy z 11 września 2015 roku o działalności ubezpieczeniowej i reasekuracyjnej ustawodawca sformułował bardzo ogólny zakres odpowiedzialności, co utrudnia jej policzenie. W praktyce zakłady ubezpieczeń muszą posiadać w działach aktuarialnych konkretny katalog szkód, które może wyrządzić pośrednik kredytu hipotecznego. Zgodnie 
z art. 33 pkt 1 Ustawy z 11 września 2015 roku o działalności ubezpieczeniowej i reasekuracyjnej zakład ubezpieczeń ustala wysokość składek w oparciu o dokonanie oceny ryzyka ubezpieczeniowego. Oczywiste jest, że zakład ubezpieczeń zmuszony jest tak ustalić wysokość składki ubezpieczeniowej, aby z wysokim prawdopodobieństwem (powyżej 0,95 ) być pewnym, że pokryją one wszystkie szkody i świadczenia, a także koszty działalności powstałe z zawartych umów ubezpieczenia.

Fundamentalne znaczenie ma ustalenie rocznego prawdopodobieństwa (częstości szkód) na podstawie posiadanych wiarygodnych danych statystycznych. Jest to niezwykle trudne podczas wprowadzania nowych produktów ubezpieczeniowych, kiedy zakład ubezpieczeń najczęściej nie dysponuje takimi danymi, a poza tym nie jest możliwe ich osiągnięcie np. ze statystyki publicznej czy też innych instytucji. Pomimo obowiązywania aktów prawnych o udostępnianiu informacji gospodarczych [Obwieszczenie Marszałka Sejmu Rzeczypospolitej Polskiej z dnia 24 maja 2014 r. ...] w dalszym ciągu występują trudności w ich uzyskaniu na potrzeby kalkulacji stóp składek. W takich okolicznościach zakłady ubezpieczeń wykorzystują pojęcie prawdopodobieństwa subiektywnego, określone za pomocą własnych ocen czy ocen ekspertów, jednocześnie tworząc rezerwy na ryzyka wyjątkowe. W praktyce wykorzystuje się pojęcie rocznej częstości szkód.

Zgodnie z pkt 33.3 ustawy o działalności ubezpieczeniowej i reasekuracyjnej zakład ubezpieczeń jest obowiązany do gromadzenia danych o szkodach, kosztach likwidacji szkód, wysokościach świadczeń. Potrzeba więc kilku lat (co najmniej dwóch), aby zgromadzić dane niezbędne do ustalenia składki ubezpieczeniowej w racjonalnej wielkości. W początkowej fazie nad wprowadzeniem nowego produktu ubezpieczeniowego konieczne jest nie tylko przestudiowanie literatury przedmiotu, potrzebna jest też wymiana doświadczeń między zakładami ubezpieczeń za pomocą Polskiej Izby Ubezpieczeń.

Roczna częstość szkód dla jednego zdarzenia (minimalna suma gwarancyjna: 460 tys. euro) jest mniejsza niż dla wszystkich zdarzeń (minimalna suma gwarancyjna: 760 tys. euro), stąd w przypadku jednego zdarzenia można przyjąć jednakową stopę składki niezależnie od wysokości minimalnej sumy gwarancyjnej. W przypadku wszystkich zdarzeń powstałych w okresie ubezpieczenia ostrożne byłoby przyjąć rosnącą stopę składki w zależności od wysokości minimalnej sumy gwarancyjnej. Warto także podkreślić, że wysokość składki ubezpieczeniowej nie może utrudniać (z punktu widzenia ekonomicznego) pracy pośrednikom kredytu hipotecznego. Ponadto składka ubezpieczeniowa nie powinna w radykalny sposób podnieść ceny kredytu hipotecznego.

Składka ubezpieczenia, jej wysokość, sposób policzenia i przyjęte założenia mogą być przedmiotem kontroli nadzoru finansowego. W szczególności zwraca on uwagę na sposób policzenia składki w ubezpieczeniach obowiązkowych. 


\section{Likwidacja szkód}

Jak w każdym ubezpieczeniu, także i w przypadku ubezpieczenia OC pośredników kredytu hipotecznego, należy się spodziewać szkód, które powstaną w czasie funkcjonowania opisywanego produktu ubezpieczeniowego. Będzie więc zachodziła konieczność likwidacji tych szkód. Do tego celu powinni być wyznaczeni likwidatorzy szkód, mający określoną wiedzę na ten temat. Zachodzi więc konieczność likwidacji szkód w analizowanym ubezpieczeniu przez osoby posiadające kwalifikacje w zakresie nie tylko szeroko pojętego ubezpieczenia odpowiedzialności cywilnej, ale i specyfiki funkcjonowania kredytu hipotecznego. Na likwidatorach szkód ciąży obowiązek ustalenia przyczyn i okoliczności szkody, ustalenie rozmiaru szkód, a także wartościowej ich wyceny w taki sposób, aby obie strony umowy ubezpieczenia były usatysfakcjonowane. W celu wypełniania zadań stojących przed likwidatorami szkód konieczne jest, aby już przed wprowadzeniem tego nowego produktu ubezpieczeniowego przeszkolić odpowiednie osoby. Należy podkreślić, że zarówno w ubezpieczeniach, jak i na rynku kredytów hipotecznych sytuacja jest dynamiczna, stąd likwidatorzy szkód powinni być okresowo szkoleni w celu nadążania nie tylko za powstającymi aktami prawnymi, ale i zdarzeniami na rynku kredytów hipotecznych. Zadaniem likwidatorów szkód jest też zapobieganie przestępczości ubezpieczeniowej; można ich też nazwać podmiotami uprawnionymi do oszacowania wysokości roszczeń.

\section{Zakończenie i wnioski}

Jak łatwo dostrzec, zakłady ubezpieczeń prowadzące działalność w II dziale ubezpieczeń zobowiązane zostały do wprowadzenia kolejnego obowiązkowego ubezpieczenia odpowiedzialności cywilnej. Dotyczy ono OC pośredników kredytów hipotecznych. Dokonując wieloaspektowej oceny związanej z wprowadzeniem tego produktu na rynek polski, obserwuje się, iż obowiązujące rozporządzenie Prezesa Rady Ministrów ma:

- ogólnikowy charakter,

- wymaga doprecyzowania poszczególnych parametrów na szczeblu zakładu ubezpieczeń,

- chroni kolejną grupę zaufania społecznego przed negatywnymi losowymi szkodami, jakie mogą spowodować pośrednicy kredytów hipotecznych.

Doprecyzowanie wielu aspektów związanych z wprowadzanym produktem jest bardzo istotne z punktu widzenia rozwoju różnych segmentów rynku. Warto zauważyć, iż w Polsce obserwowany jest ciągły rozwój pierwotnego rynku nieruchomości mieszkaniowych, co generuje konieczność jego finansowania. Pewien odsetek nabywców lokali mieszkalnych korzysta z usług pośredników hipotecznych, oczekując wskazania adekwatnego produktu, co wymaga posiadania przez nich odpowiedniej wiedzy, znajomości rynku kredytów hipotecznych oraz rodzajów ryzyka, które 
towarzyszą zawieraniu umów o kredyt hipoteczny. Wprowadzenie obowiązkowego ubezpieczenia odpowiedzialności cywilnej powinno przyczynić się do rzetelnego uzupełniania wiedzy przez pośredników kredytów hipotecznych.

Podjęta tematyka dotycząca ubezpieczenia OC pośredników kredytów hipotecznych nie została wyczerpana. Ograniczone ramy artykułu spowodowały, że problematyka ta została jedynie zasygnalizowana. Konieczne są dalsze badania i obserwacje.

\section{Literatura}

Amron Sarfin, 2017, Ogólnopolski raport o kredytach mieszkaniowych i cenach transakcyjnych nieruchomości, 3/2017, https://zbp.pl/raporty/raport-amron-sarfin, listopad (21.02.2018).

Główka G. (red.), 2008, Nieruchomość, kredyt, hipoteka, Poltext, Warszawa.

Kalasińska M., 2010, Kredyty i pożyczki hipoteczne jako podstawowe źródło finansowania nieruchomości, [w:] Wspótczesna bankowość hipoteczna, red. A. Szelągowska, CeDeWu, Warszawa.

Komisja Nadzoru Finansowego, 2011, Rekomendacja S dotyczaca dobrych praktyk $w$ zakresie zarzadzania ekspozycjami kredytowymi finansujacymi nieruchomości oraz zabezpieczonymi hipotecznie, Warszawa.

Kowalczyk-Rólczyńska P., 2015, Finansowanie rynku nieruchomości, [w:] Rynek nieruchomości w Polsce. Teoria i praktyka, D. Ostrowska, P. Kowalczyk-Rólczyńska, P. Jamróz, A. Staniszewska, E. Spigarska, M. Staśkiel, Wolters Kluwer, Warszawa.

Łaszek J. (red.), 2017, Raport o sytuacji na rynku nieruchomości mieszkaniowych i komercyjnych w Polsce w 2016 r. Departament Analiz Ekonomicznych, Narodowy Bank Polski, Warszawa, wrzesień.

Mędrała K., 2012, Ubezpieczenie od kredytów, Miesięcznik Ubezpieczeniowy, styczeń.

NBP, 2006, Rozwój systemu finansowego w Polsce w 2005 r., Warszawa.

NBP, 2017, Rozwój systemu finansowego w Polsce w 2016 r., Warszawa.

Ostrowska D., Kowalczyk-Rólczyńska P., Jamróz P., Staniszewska A., Spigarska E., Staśkiel M., 2015, Rynek nieruchomości w Polsce. Teoria i praktyka, Wolters Kluwer, Warszawa.

Rybicki P., 2017, Kredyt hipoteczny. Najważniejsze pytania, Poligraf.

Słowik P., 2015, Kredyty będą droższe. To cena bezpieczeństwa, Dziennik Gazeta Prawna, 16 lutego.

Staniewski A., 2008, Kredytowe ryzyko, Miesięcznik Ubezpieczeniowy, styczeń.

Szelągowska A. (red.), 2010, Współczesna bankowość hipoteczna, CeDeWu, Warszawa.

Waliszewski K., 2017, Zmiany w pośrednictwie kredytowym w Polsce w wyniku implementacji dyrektywy hipotecznej, Rozprawy Ubezpieczeniowe. Konsument na Rynku Usług Finansowych, nr 24 (2/2017).

Obwieszczenie Marszałka Sejmu Rzeczypospolitej Polskiej z dnia 24 maja 2014 roku w sprawie ogłoszenia jednolitego tekstu ustawy o udostępnianiu informacji gospodarczych i wymianie danych gospodarczych, Dz.U. 2014, poz. 1015, z późn. zm.

Rozporządzenie Ministra Finansów z dnia 7 lipca 2005 roku w sprawie minimalnego zakresu szkolenia osób ubiegających się o wykonywanie czynności agencyjnych oraz zakresu obowiązujących tematów egzaminów i trybu jego przeprowadzenia, Dz.U. nr 125/2005, poz. 1059, z późn. zm.

Rozporządzenie Ministra Rozwoju i Finansów z dnia 19 lipca 2017 r. w sprawie obowiązkowego ubezpieczenia odpowiedzialności cywilnej pośrednika kredytu hipotecznego, Dz.U. 2017, poz. 1403.

Rozporządzenie Prezesa Rady Ministrów z dnia 3 października 2017 roku w sprawie wpłat na pokrycie kosztów nadzoru nad pośrednikami kredytu hipotecznego, Dz.U. 2017, poz. 1914. 
Rozwój systemu finansowego w Polsce, http://www.nbp.pl/home.aspx?f=/systemfinansowy/rozwoj. html (21.02.2018).

The Mortgage Credit Directive 2014/17/EU (MCD), Komisja Europejska (2014), Dyrektywa 2014/17/ UE Parlamentu Europejskiego i Rady z dnia 4 lutego 2014 r. w sprawie umów o kredyt konsumencki dotyczących nieruchomości mieszkalnych i zmieniająca dyrektywy 2008/48/WE i 2013/36/UE oraz rozporządzenie (UE) nr 1093/2010, Dz. Urz. UE, 33 (60): 34-85, aktualizacja: 9.06 .2016 .

Ustawa z dnia 12 maja 2011 roku o kredycie konsumenckim, tekst jednolity Dz.U. 2016, poz. 1528, 2017, poz. 819 .

Ustawa z dnia 11 września 2015 roku o działalności ubezpieczeniowej i reasekuracyjnej, Dz.U. 2015, poz. 1844.

Ustawa z dnia 25 marca 2017 roku o kredycie hipotecznym oraz o nadzorze nad pośrednikami kredytu hipotecznego i agentami, Dz.U. 2017, poz. 819. 